\title{
Perspectives
}

\section{Mind the Gap: How a Project in Alberta Attempted to Narrow the Gap Between Classroom Teachers and Language Education Research}

\author{
Justine Light and Sara Gnida
}

This article presents the development, rollout, and subsequent uptake of the Alberta Teachers of English as a Second Language (ATESL) document Best Practices for Adult English as a Second Language (ESL)/Language Instruction for Newcomers to Canada (LINC) Programming in the light of literature on teacher engagement with second-language acquisition and teaching research. The first part of the Best Practices project was designed to develop a set of best practice statements of principle developed in collaboration with language education experts in Alberta and through the professional literature, as well as with ESL teachers across the province. In the second part of the project, we facilitated the uptake of the principles by teachers and administrators throughout Alberta.

Cet article présente le développement, la mise en œuvre et l'adoption subséquente du document des enseignants albertains de l'ALS portant sur les meilleures pratiques pour l'ALS aux adultes et le programme cours de langue pour les immigrants au Canada (CLIC) et ce, à la lumière de l'implication des enseignants dans la recherche portant sur l'acquisition et l'enseignement de langues secondes. La première partie du projet des meilleures pratiques visait le développement d'une série de déclarations de principes élaborées en collaboration avec des experts en enseignement de la langue, appuyées par la littérature spécialisée et des enseignants en ALS de partout en Alberta. La deuxième partie du projet visait à faciliter l'adoption des principes par les enseignants et les administrateurs à travers l'Alberta.

The development and rollout of Best Practices for Adult ESL and LINC Programming in Alberta (Alberta Teachers of English as a Second Language [ATESL], 2009), undertaken by Alberta Teachers of English as a Second Language (ATESL), is an example of the principled attempt of a professional organization to bridge the divide between the ESL teaching profession in its region and the available research about teaching and learning. 
The roots for the Best Practices project can be traced back to 1992, when the federal government implemented the Language Instruction for Newcomers to Canada (LINC) program. The subsequent increased funding for language instruction across Canada resulted in the emergence of many new programs offered by nontraditional providers. In ATESL there was growing concern regarding what was perceived as an increasing divide between ESL teaching practice and second-language acquisition (SLA) and teaching English as a second language (TESL) theory and research. This concern over the quality of language instruction was not limited to Alberta, and its timing coincided with TESL Ontario and TESOL initiatives to standardize the certification of ESL teachers (Cleghorn, 2000). In 1994, in response to this concern, ATESL drafted the original Best Practice Guidelines for Adult ESL/LINC Programming and Instruction in Alberta. This document, which was revised in 2004, was one of the first of its kind to specify a list of quality practices (best practices or standards) related to adult ESL programming. However, it did not adequately deal with the pedagogical issues that ATESL believed had to be addressed if ESL pedagogy in Alberta was to conform more closely to SLA/TESL principles. There was a perceived need for a document that would (a) clearly reflect SLA and instruction principles, and (b) be accessible and useable for all involved in ESL programming (instructors, administrators, and funders). To this end, an updated Best Practices document was commissioned.

In this article we present the development, rollout, and subsequent uptake of the Best Practices project in the light of the literature on teacher uptake of SLA and teaching research.

\section{Teachers and Research}

Before discussing the role of ATESL's Best Practices document in bridging the often cited gap between English-language teachers and researchers, it is necessary first to consider in more detail why such a gap might exist, how teachers may use research to make decisions in the classroom, and which approaches to teachers' engagement with research might be most effective.

Although the literature recognizes the benefits of engaging teachers in research, research by teachers remains "a minority activity in ELT" (Borg, 2009 , p. 377). The possible causes of teachers' lack of engagement in, or with, research have been widely acknowledged (Erlam, 2008). Labaree (2003) describes the views of teachers and researchers as being diametrically opposed at almost every turn. According to Labaree, classroom teachers' views about language teaching and learning are normative, personal, particular, and experiential, in contrast to researchers' views, which are analytical, intellectual, universal, and theoretical. In a somewhat less rigid portrayal, Ellis (1997) describes the differences between teachers and researchers as centering on the technical knowledge that is the goal of SLA research and the procedural 
knowledge that is the goal of pedagogy. The technical knowledge of SLA research is explicit knowledge that can be tested, whereas the procedural knowledge of teachers is implicit and intuitive and is acquired through classroom experience. Ellis (2005) outlines some approaches to rendering technical knowledge more accessible to practitioners. He suggests that teachers are more likely to engage with research-based principles that are relevant to their classrooms; in other words, they are more likely to engage with accessible language-learning principles that can be tested in their own individual contexts.

In a New Zealand-based research project, Erlam (2008) examined the effect of presenting research-based principles to language teachers, as well as presenting both the principles and evidence from a classroom-centered research study to language advisors. These principles of instructed languagelearning were modified from those proposed by Ellis (2005). Ellis's original principles had been written as an attempt to draw together evidence from SLA to inform language pedagogy; the adapted principles enabled Erlam to record observable behaviors. Although Erlam did not present data to evaluate the uptake of the principles in classroom teaching practice, the project was evaluated as successful based on the wide distribution of the documents associated with it, the uptake of the principles by the language advisors responsible for evaluating classroom teachers, and feedback from language advisors about the positive response of teachers to the documents.

The principles of instructed language-learning provided a benchmark against which teachers could compare their own classroom contexts; that is, the principles and case studies invited teachers' engagement rather than requiring their compliance (Erlam, 2008). Furthermore, the principles allowed for local classroom testing and created a new, shared language that teachers could use collaboratively in discussion. Erlam attributes the language teachers' and advisors' enthusiasm for the principles to the following factors.

- The accessibility of the technical knowledge presented through the clearly articulated statements.

- The development of the principles as a reflective tool that invited teachers to determine the applicability of the individual principles to their teaching context, which in turn validated their experience. Thus practitioners were able to own the research.

On a purely practical level, teachers may not have the time or energy to engage with language education research. In the complex world of teachers' decision-making, termed by Borg (2003) as "teacher cognition," teachers make many decisions in one teaching day, and many of these decisions have little to do with the considerations presented in the TESL/SLA research. In his review of the literature on teacher cognition, Borg cites numerous research studies that describe the plethora of cognitive influences on teachers' decisions. Several studies demonstrate that classroom teachers prioritize in- 
structional considerations above language-acquisition concerns. In her study of six preservice ESL teachers, Johnson (1992) found that students' motivation, curriculum integration, affective needs, and pedagogical principles (along with other considerations) informed the teachers' classroom decisions. Furthermore, Woods's (1996) study of Canadian ESL teachers refers to the following factors as affecting one teacher's decision-making: how many students would attend that day, the availability of photocopying, a recent conversation with another teacher, and class dynamics. These ESL teachers' concerns are far removed from the considerations of second-language researchers, which perhaps points to why with their limited time and resources, teachers often do not prioritize the time and the effort to access, read, and apply research findings to their contexts.

In promoting the role of teachers as consumers of academic research, Borg (2010) identifies four erroneous assumptions that are often made: "(1) teachers have access to published research; (2) teachers want to read published research; (3) teachers need to read published research; and (4) teachers have the time to read such material" (p.410). Borg points out that although these assumptions may hold true for teachers formally engaged in a university program, they do not apply to language teachers in their workplace context.

In the light of the disconnect that can exist between research and classroom practice, as well as the multiple potential underlying causes for such a gap, the importance of presenting user-friendly, contextually adaptive, consumer-driven teaching and learning principles is clear. The research of Ellis (2005), Erlam $(2008)$, and Borg $(2007,2010)$ presents a compelling rationale for the need not only to engage teachers as critical consumers, but also to present modified, accessible summaries or versions of research against which teachers can compare their classroom practices.

\section{The ATESL Best Practice Project}

In many ways, the goal of ATESL's Best Practices project was to "[forge] a second language acquisition-language pedagogy nexus" (Ellis, 2010, p. 4). The Best Practices for Adult ESL and LINC Programming in Alberta project, both in the development of the document and through its subsequent rollout, sought to engage ESL professionals (teachers, administrators) and to provide access to technical knowledge through an accessible summary of ESL teaching and learning research.

\section{Development of the Best Practices Document}

One mandate for the Best Practices document was that it be based on current research in SLA and TESL. To this end, the project began with a meeting with TESL academics at the University of Alberta and an exploration of the published research and theory related to many aspects of SLA, ESL instruction, and ESL programming. Acknowledged experts in the ESL field in Alberta 
Table 1

Best Practices Summary

Content of Best Practices for Adult ESL and LINC Programming in Alberta

\begin{tabular}{|c|c|c|}
\hline $\begin{array}{l}\text { Best Practice } \\
\text { Statements }\end{array}$ & \multicolumn{2}{|c|}{$\begin{array}{l}\text { Includes } 67 \text { statements of best practice, organized } \\
\text { according to } 9 \text { themes. }\end{array}$} \\
\hline \multirow[t]{10}{*}{ Best Practice Guidelines } & \multicolumn{2}{|c|}{$\begin{array}{l}\text { Each of the following themes includes best practice statements, } \\
\text { indicators for each best practice, and a reference list. }\end{array}$} \\
\hline & The Program: & $\begin{array}{l}\text { mission, philosophy, goals, finances, } \\
\text { administration, planning, marketing, } \\
\text { scheduling and delivery, evaluation, } \\
\text { collaboration with other organizations, } \\
\text { learner/instructor ratio }\end{array}$ \\
\hline & Learner Support: & $\begin{array}{l}\text { orientation, communication, support } \\
\text { services, community participation, } \\
\text { transition }\end{array}$ \\
\hline & Staff: & $\begin{array}{l}\text { qualifications, hiring, orientation, pro- } \\
\text { fessional development, compensation, } \\
\text { ethical treatment, evaluation }\end{array}$ \\
\hline & $\begin{array}{l}\text { Canadian Language } \\
\text { Benchmarks: }\end{array}$ & $\begin{array}{l}\text { professional development, standard } \\
\text { frame of reference, curriculum, } \\
\text { materials, instruction, resources }\end{array}$ \\
\hline & Curriculum: & $\begin{array}{l}\text { articulated, flexible, responsive, } \\
\text { regularly renewed, reflecting program } \\
\text { mission and SLA principles }\end{array}$ \\
\hline & Instruction: & $\begin{array}{l}\text { learner oriented, listening, speaking, } \\
\text { reading, writing, grammar, pronuncia- } \\
\text { tion, vocabulary, technology, culture, } \\
\text { autonomous learning }\end{array}$ \\
\hline & Learner Assessment: & $\begin{array}{l}\text { placement, ongoing formative feed- } \\
\text { back, summative assessment, high } \\
\text { stakes, documentation }\end{array}$ \\
\hline & Resources: & $\begin{array}{l}\text { location, facilities, classroom materials, } \\
\text { equipment, teaching/learning resources }\end{array}$ \\
\hline & ESL Literacy: & $\begin{array}{l}\text { placement, instructor qualifications } \\
\text { and support, the literacy classroom, } \\
\text { enhanced support services }\end{array}$ \\
\hline
\end{tabular}

Putting Best Practices

How to use the document for self-reflection, program into Practice self-evaluation, and identification of effective programs.

Appendices Report, references, evaluation tool 
were also involved in the final stage of producing the document as they reviewed particular sections, which were then revised based on their feedback. See Table 1 for a summary of the Best Practices document.

A second mandate of the project was that the content and format of the document be grounded in the particular needs and practices of professionals in Alberta who were involved in providing ESL instruction. To this end, focus groups and an online questionnaire were used to gather input from participants representing programs in Calgary, Edmonton, and North, South, and Central Alberta (because there was only one respondent from Northern Alberta, this took the form of a telephone interview). Participants were asked for input in a number of areas, including (a) how they would use a document detailing the Best Practices for ESL E LINC programs in Alberta, and (b) what they considered to be best practice in a number of areas. This question was addressed in a "graffiti" activity, where participants wrote "best practices" on posters with predetermined "themes" (Staff, Instruction, Curriculum, Canadian Language Benchmarks and Essential Skills, Assessment/Learner gains, Program structure/administration, Learner support, and Resources). Later, participants rated the contributions on the posters as being more important or less important, and contributions were discussed in the large group. Data from the focus group interviews were gathered from what respondents recorded on flip chart paper during the setting-the-stage questions, the graffiti activity, and the discussion of the themes, as well as from the check marks that distinguished more important from less important issues. The focus group interviews were also recorded, and notes were made of the discussions. The data from the focus group interviews, along with data from the online questionnaire, were categorized according to theme. These data then informed the layout and content of the Best Practices document.

Responses to the first question, "How would you use a document detailing the best practices for ESL \& LINC programs in Alberta?" affected the format of the ultimate document. Focus group participants specified that they wanted a document that would allow them to do the following:

- reflect on and evaluate their own practice;

- compensate for gaps in knowledge or training;

- spark dialogue and discussion among coworkers;

- evaluate programs (i.e., from both funders' and administrators' perspectives).

Focus group participants also specified that the document needed to

- include guidelines for practice in selected areas;

- inform program practice;

- provide assistance in writing and justifying proposals for funding;

- encourage improvement of funded programs;

Based on this input, it was clear that a list of best-practice statements alone would be insufficient to meet the needs of the respondents. For this reason, indicators are provided for every best practice, identifying how to meet the 
Table 2

Sample Best Practice, \#48a with indicators

48. (a) Vocabulary instruction encourages learners to notice and focus on new vocabulary items (single words as well as formulaic sequences) and links the forms of new vocabulary to meanings, collocations, and uses.

Learners are encouraged to notice and focus on new words, their meanings, uses, and pronunciation, in a variety of ways:

- Explicit discussion of target vocabulary prior to listening, speaking, reading or writing tasks.

- The incorporation of target vocabulary in pre-listening/reading activities to ensure multiple recalls of the items.

- Lexical elaborations (glosses) and textual enhancement in both paper and electronic readings.

- The use of visuals, e.g., writing vocabulary items on board, flip chart paper, etc.

- Presentation of new, thematically-related items prior to a unit in which the theme is explored through a variety of activities and modes.

expectations set by that best practice. For example, Table 2 illustrates Best Practice 48a followed by some of the indicators that are used to illustrate and clarify the best practice.

Also, each section of the document provides a list of suggested readings and the references that informed that section. An implementation guide provides guidance for instructors, administrators, and funders in their use of the document.

Responses to questions asking what participants considered to be best practices in a variety of broad areas helped us to identify the specific aspects of pedagogy and practice that needed to be addressed in the document. In this sense, the content of the Best Practices project differs from the content of Erlam's (2008) project in that it was the practitioners, not the researchers, who identified which issues were especially important and should be addressed. In the case of the methodology section of the document (titled Instruction), the focus groups identified the issues to be addressed (e.g., pronunciation, grammar, and vocabulary instruction), but the professional/academic literature provided the substance. In other sections of the document, the focus groups provided more of the content of that area, and the literature was used to expand on and/or validate this content. For example, the importance of facilitating, encouraging, acknowledging, and rewarding professional development, along with suggested ways of doing so, were first verbalized in the focus groups and then validated by the literature. The resulting Best Practice reads: "The program facilitates, encourages, acknowl- 
edges and rewards participation in professional development" (BP \#26). It is followed by numerous indicators listing how programs can meet this best practice, including, for example,

- Rescheduling of classes to allow staff to attend conferences;

- Release time or support for leadership/involvement in TESL organizations;

- Opportunity to apply what is learned through program innovations, pilot course, etc.

\section{Rollout of the Best Practices Document}

Once the document was revised and printed, workshops for instructors and administrators were developed and presented throughout Alberta. The workshops were offered to all ATESL members through the local ATESL boards; and workshops were also offered through a variety of institutions. Presentations were also offered at TESL Canada conferences in 2009 and 2011.

The goal of the workshops was to familiarize instructors and administrators with the Best Practices document and to allow them to identify how they could make use of the document. All workshop participants received a copy. During the workshops, the process of how the manual came to be was presented to participants: this was viewed as important for the validity of the document in order for it to be recognized as rooted in both the literature and the Alberta adult ESL context. After a survey of the document, instructors considered how they might use it as they worked through a variety of case studies. They engaged in activities that demonstrated how the document could be used as a tool for reflective practice and as a catalyst for discussion among peers. Administrators considered how they might use the document for program evaluation, discussing the evidence they could gather (a) to demonstrate that best practices were being met, and (b) to identify areas for improvement.

\section{Uptake of the Best Practices Document}

The Best Practices document has been widely disseminated in Alberta. Teachers and administrators enthusiastically participated in workshops that for many occurred outside paid time. These workshops were voluntary and took place over approximately four months (March-June, 2010). In total, 12 instructors' workshops (with a total of 150 participants) and nine administrators' workshops were held (with more than 100 participants). Once the workshops were completed, the document was posted in its entirety on the ATESL Web site. It consistently received a large number of hits each month, as demonstrated in May 2011 when it received 390 hits, most of which resulted in downloading the full version of the document (ATESL Web data, May 2011).

Nine months later in March 2011, a survey was sent to all ATESL members (551 in total) to determine the uptake on the Best Practices document. We received 58 responses (an 11\% response rate; three similar research surveys sent to ATESL members in 2012 elicited response rates of 5\%, 9\%, and 12\%). 
Only half the respondents had attended an ATESL Best Practices workshop and so had received a copy of the document, and of those, $86 \%$ had found the workshops very or somewhat useful. However, a total of $78 \%$ of respondents $(n=45)$ indicated that they had used the document in some way, suggesting that use of the document has gone beyond the workshop participants. Although most people $(48 \%, n=28)$ had used the document only once or twice, $16 \%(n=9)$ had used it three to four times, and $11 \%(n=6)$ were using it regularly; $27 \%$ indicated that they had never used the document. All those who had used the document found it useful and flexible $(43 \%, n=25)$ or somewhat useful and flexible $(24 \%, n=14)$ in their context.

The survey asked ATESL members how they made use of the Best Practices document. Results of the survey indicated that the document was most commonly used for reflection either on one's own practice $(58 \%, n=34)$ or on the practices of one's program $(63 \%, n=36)$. Respondents were also making use of the document to find out more about a particular area of ESL pedagogy $(37 \%, n=21)$ and ESL programming $(36 \%, n=21)$. Others reported using it to provide professional development for instructors or volunteers $(30 \%, n=17)$; to write a paper, report, or project for a TESL class $(19 \%, n=11)$; and to support an application for funding $(7 \%, n=4)$.

The two sections of the document that people considered the most useful were entitled Instruction and Resources, with $70 \%(n=41)$ of respondents indicating that they were very useful or useful (see Table 3). Other sections

Table 3

Responses to Question: "Which themes in the BP document have been of most use to you (please check all that apply)?"

\begin{tabular}{llllc}
\hline Section & $\begin{array}{c}\text { Very } \\
\text { useful }\end{array}$ & Useful & $\begin{array}{c}\text { Not } \\
\text { useful }\end{array}$ & $\begin{array}{c}\text { Not sure or } \\
\text { Does not apply } \\
\text { to my context }\end{array}$ \\
\hline The program & $25 \%$ & $36 \%$ & $6 \%$ & $33 \%$ \\
Learner support & $18 \%$ & $50 \%$ & $3 \%$ & $29 \%$ \\
The staff & $15 \%$ & $27 \%$ & $9 \%$ & $50 \%$ \\
Canadian Language & $24 \%$ & $38 \%$ & $5 \%$ & $22 \%$ \\
Benchmarks & $35 \%$ & $32 \%$ & $5 \%$ & $32 \%$ \\
Curriculum & $\mathbf{3 2 \%}$ & $\mathbf{3 8 \%}$ & $\mathbf{5 \%}$ & $\mathbf{2 4 \%}$ \\
Instruction & $29 \%$ & $37 \%$ & $3 \%$ & $31 \%$ \\
Learner assessment & $\mathbf{3 1 \%}$ & $\mathbf{4 0 \%}$ & $\mathbf{3} \%$ & $\mathbf{2 8 \%}$ \\
Resources & $16 \%$ & $35 \%$ & $3 \%$ & $46 \%$ \\
ESL Literacy & & & & \\
\hline
\end{tabular}

(Total number of respondents $=58$ ). 
ranked as very useful or useful by over $60 \%(n=35)$ of respondents were Learner Support (68\%, $n=39)$, Curriculum $(68 \%, n=39)$, Learner Assessment (66\%, $n=38)$, and Canadian Language Benchmarks (62\%, $n=36$, see Table 3).

Forty-six percent $(n=27)$ of respondents indicated that the Best Practices manual had affected their practice in some way. In their written responses to this question, some indicated that they were using the document as a reference or to access knowledge.

- "It has given me a very thorough reference to use."

- "It has proven to be a very useful benchmark tool."

- "Provides one with more background knowledge/information."

- "I think the document articulates what I already know; it's nice to have it all laid out in an easy to use format for reference. I find I'm using it more as time goes on. When recently negotiating with our funder for next year, I made several references to it to 'argue' my points."

Other written responses indicate that some were using the document in a more aspirational way.

- "Helped me establish a vision."

- "It provides a benchmark to aspire to."

- "Increased awareness; new directions."

Other written responses referred to using the document to reflect on their own practice:

- "It has clarified my thinking about my teaching practice in a number of areas."

- "It has made me reflect more on my practices."

- "It is the guide to keep me on track and aware."

Responses to the survey also highlighted frustrations related to the Best Practices document. The first, mentioned by two respondents, was related to the generic nature of best practice documents (e.g., "Too generic and do not feel like they apply to individual cases"). The second frustration, also expressed by two respondents, was that the Best Practices were not being followed (or perhaps not being enforced), especially with regard to hiring and program administration.

- "BP is just a recommendation, so most of it is not implemented by the administration in the context of the Staff. ... The Best Practices could be really useful if they are really followed by the administration, which unfortunately is not the case. Many teachers follow it without any recognition or appreciation."

- "It carries no weight at all. ESL directors/coordinators can do what they want-I have seen this over and over again.... What is the good of a document that means nothing?"

These frustrations perhaps related to a choice early in the project to produce an aspirational Best Practices document rather than imposing a Standards document. The focus of the project was to be aspirational in terms of describing 
optimal conditions for language-teaching and learning. Beyond these parameters, it was determined at the outset of the project that the use of the document for imposing standards would be entirely another undertaking.

\section{Conclusion}

Based on the distribution of the document, the engagement of teachers, the perceived accessibility of the document, and the relevance of the technical knowledge that it provided, ATESL's Best Practices for Adult ESL and LINC Programming in Alberta has successfully served as one bridge for the divide between the ESL teaching profession in Alberta and the available research about teaching and learning.

Distribution. The document has been widely distributed in Alberta. The workshops provided one means of disseminating it. From the survey, however, it is clear that distribution of the document has gone beyond the original method through the workshops. Not only is it being widely accessed and downloaded through the ATESL Web site, but it has been further distributed through class sets available to university TESL diploma and master's programs that focus on adult ESL.

Engagement. Anecdotal and enthusiastic responses to the workshops, as well as evidence from the online survey, indicated that teachers and administrators in Alberta were enthusiastic about the document. It should be noted, however, that there could be a response bias in the survey results: those who felt positively about the Best Practices document may have been more likely to respond.

Accessibility. The survey indicated that those who attempted to use the document found it flexible and usable or somewhat flexible and usable.

Access to technical knowledge (i.e., SLA and teaching research/principles). TESL experts and academics were involved in the inception of the project; the research literature informed the writing of the document; and the document was then revised based on expert and academic feedback. This extensive peer-review and validation process has ensured that the document is providing valid technical knowledge to ESL providers in Alberta.

Through the measures of distribution, engagement, document accessibility, and access to technical knowledge, classroom teachers have demonstrated their willingness to become engaged as expert consumers of research whose own contexts will ultimately determine the usefulness of that research. Recognizing that SLA and teaching research is ongoing, ATESL is committed to a five-year revision process to ensure that the content of the document continues to reflect current understandings and findings in the profession. All funders and service providers and many administrators and instructors have been provided with the document, and all have online access to it. To ensure continued engagement with the document, we recommend that TESL teacher education programs integrate the Best Practices document into their coursework. ATESL could continue to promote the document through dis- 
tribution of copies at conferences and as part of new-member packages. We also recommend that service providers ensure that the document continues to be available to new instructors and that they encourage instructors' engagement with it by using it in professional development.

For others in the field who seek to engage instructors with ESL teaching and learning research, we recommend a process that actively consults, takes time to engage with all stakeholders (including instructors), and integrates their feedback in a value-added way. An important factor in the success of ATESL's Best Practices project was that the process was truly consultative and engaged all stakeholders. Teachers, researchers, administrators, funders: all had a voice that was equally valued. Most critical in this was that instructors had a voice in describing their own needs and that the resulting principles reflected the realities of their lives in the classroom.

\section{The Authors}

Justine Light is a sessional instructor in the University of Alberta TESL program and teaches EAP. She is a member of the CCLB National Registry of CLB experts and manages the Learning English with CBC project.

Sara Gnida is an instructor and curriculum developer with more than 20 years of ESL experience in Edmonton and overseas. Her current interests include English for internationally trained nurses, EAP, curriculum development, and professional development for instructors. Previous projects include ATESL's Best Practices document and an online writing workshop for nurses.

\section{References}

Alberta Teachers of English as a Second Language (ATESL). (2009). Best practices for adult ESL and LINC programming in Alberta. Edmonton, AB: Author.

Belcher, D. (2007). A bridge too far? TESOL Quarterly, 41, 396-399.

Borg, S. (2003). Teacher cognition in language teaching: A review of research on what language teachers think, know, believe, and do. Language Teaching, 36(2), 81-109.

Borg, S. (2007). Research engagement in English language teaching. Teaching and Teacher Education, 23, 731-747.

Borg, S. (2009). English language teachers' conceptions of research. Applied Linguistics, 30, 358-388.

Borg, S. (2010). Language teacher research engagement. Language Teaching, 43, 391-429.

Cleghorn, L. (2000). Valuing English: An ethnography of a federal language training program for adult immigrants. Unpublished master's thesis. University of Toronto.

Ellis, R. (1997). SLA research and language teaching. Oxford, UK: Oxford University Press.

Ellis, R. (2005). Principles of instructed language learning. System, 33, 209-224.

Ellis, R. (2010). A principled approach to incorporating second language acquisition research into a teacher education programme. Reflections on English Language Teaching, 9(1), 1-17.

Erlam, R.M. (2008). What do you researchers know about language teaching? Bridging the gap between SLA research and language pedagogy. Innovation in Language Learning and Teaching, 2, 253-267.

Johnson, K.E. (1992). Learning to teach: Instructional actions and decisions of preservice ESL teachers. TESOL Quarterly, 26, 507-535.

Labaree, D.F. (2003). The peculiar problems of preparing educational researchers. Educational Researcher, 32(4), 13-22.

Woods, D. (1996). Teacher cognition in language teaching: Beliefs, decision-making and classroom practice. Cambridge, UK: Cambridge University Press. 